\title{
新潟県・大潟町の請負耕作
}

\section{川上 誠*}

\begin{abstract}
請負耕作 (ヤミ小作)は全国各地で発生しているが，なかでも新潟県は多い，その新潟県内でも，大潟町は 有数の請負耕作多発地である. 本稿では, その多発理由, 委託集落と受託集落の分化, 委託形成における主 婦の役割，委託への「段階的移行」を地域労働市場の展開と農業構造のかかわりから明らかにした．また； 受託農家の性格と受託農家の規模拡大過程を調べ, さらに減反政策のもとで請負耕作が発生・展開する理由 も考察した.

工場進出にともなう地域労㗢市場の展開は, 委託農家の創出条件である. それゆえ, 請負耕作は今後も增 加するとみられる. 請負耕作は「戦後自作農」の崩壞であり, 新しい経営形態の一つの形成でもある.
\end{abstract}

\section{I まえがき}

ここで扱う請負耕作は，いわゆる「ヤミ小作」の ことで，個別農家間の土地賃貸借（主として下層の 委託・上層の受託)によって成立する「生産関係」で ある.

請負耕作は昭和30年代前半から発生しはじめたが, 法の網(農地法)をくぐる農地の賃貸借関係のため, 無視一見ぬふり(行政側) ・陰蔽(農家側)される傾向 が強い，その唯一の手がかりである「農業調査」も 調査精度は低いとみなければならない1)。こうした ことが請負耕作の実態把握を困難にしてきた。しか しながら，請負耕作は農業の根幹にふれるものであ るため，多くの研究がなされてきた（伊藤，1966， 1973 ; 近藤, 1967 ; 倉内, 1976 ; 梶井, 1977). 地理 学分野では, 高橋(1977)が組織的請負耕作に積極的 にとりくみ，松井(1968)の永年にわたる「稲作生産 組織」の研究の中にも請負耕作が含まれている．ま た筆者も蒲原平野を事例としてふれた(川上, 1972).

調査精度が低いために，ある程度の制約を考慮し なければならないが，「農業調査」(昭和 46 年)によれ ば，北陸地方は請負耕作の多発地域で(委託農家率: 北陸 $1.5 \%$ ，都府県0.8\%，受託農家率：北陸 $2.0 \%$ ， 都府県 $0.6 \%)$, なかでも新潟県は多い(受託農家率:

\footnotetext{
* 都立羽田工業高等学校
}

新潟県 $3.6 \%$, 石川県 $2.0 \%$, 福井県 $0.4 \%$, 富山県 $0.2 \%$ )(北陸農政局，1971）。昭和42年，新潟県農林 部が実施した請負耕作の市町村別調查は，それが蒲 原平野と頸城平野に多発集中していることを示して いる(新潟県農林部，1968)。とくに蒲原平野の14市 町村(豊栄市，小須戸町，村松町，新津市，白根市， 岩室村, 吉田町, 燕市, 月潟村, 巻町, 潟東村, 三 島町, 与板町, 寺泊町) と頸城平野の 2 町村 (大潟町, 頸城村)で多い(以上の市町村は受委託面積率 $2 \%$ 以 上, 県平均 $1.1 \%$ 弱).

調査地の大潟町は受委託農家率で頸城平野の各市 町村中第 2 位, 面積率で第 1 位を占める(委託面積 率 $3.4 \%$ ，受託面積率 $3.3 \%)$ ．本稿では大潟町の(1) 請負耕作の多発理由とそれが主として「浜」農家(委 託)と「在」農家 (受託)で行なわれてきた理由，ま た，近年町外の農家へ委託が増加してきた理由，(2) 「自作」から委託への移行過程で主婦が果たしてい る役割, (3)委託移行の態様, (4)受託農家の性格と耕 作規模拡大の実態，(5)減反政策と請負耕作の関係な どを明らかにしょうとするものである.

\section{II 大渴町の概況}

大潟町は上越市直江津地区と頸城村，吉川町，柿 崎町にはさまれ，日本海に面する町で，まったく性 格を異にする二つの地域からなっている(第 1 図). 


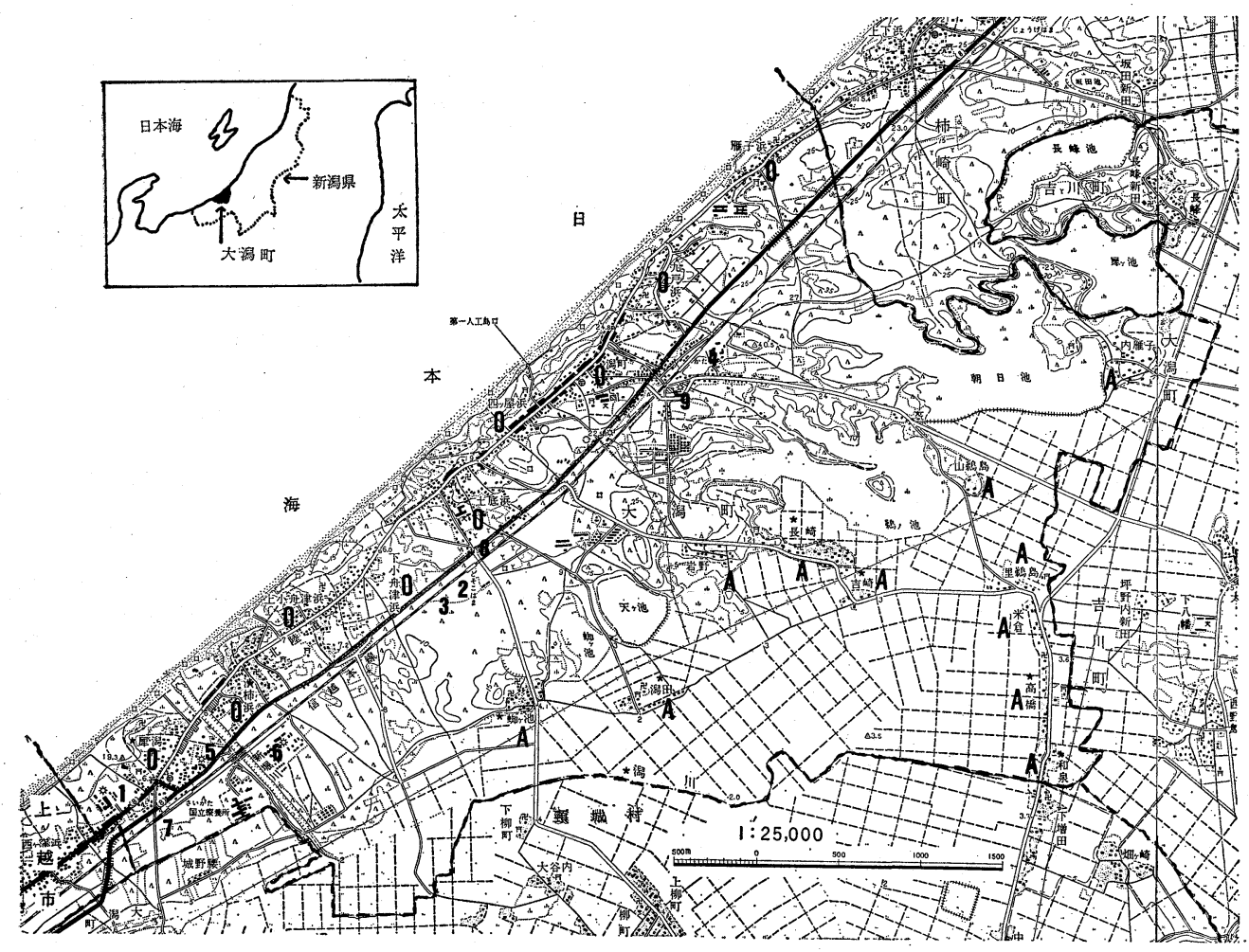

第 1 図大潟町位置図

$\mathrm{A}$ : 「在」集落 0 : 「浜」集落. 1. 第一工業製薬 2. 丸大食品 3. 大潟ブルボン 4. 帝国石油 5 . 犀潟 鉄工 6. 帝石トッピング 7. 新潟くみあい飼料 8. 新潟バルブ 9. ウチダ和漢薬.

「浜」と呼ばれる諸集落が立地する砂丘地域と「在」 といわれる集落のある砂丘地背後の水田地域である. 前者は高燥なため畑地として利用されてきたが，ま だ広い林地を残している. そのため隣接の直江津地 区に比べれば地価が安い.ここには直江津に通ずる 新旧国道(旧国道はバス路線), 信越線 (町内に 3 駅設 置)が走っている. 昭和 35 年以降, 工場進出や住宅 の建設が進んだが，それはこうした地域条件による。 役場, 農協, 学校, 郵便局, 銀行とほとんどの商店 はこの地域にあり, 2 ・3次産業従事者が多く, 非農 家が64\% (1,376戸)を占める. これに対し, 砂丘地 背後に拡がる水田地域は, 純農村地域であって, 非 農家は 5 \% (11戸)にすぎない.

\section{III 委託集落と受託集落の分化}

請負耕作は一般に，発生当初においては同一部落 農家間で行なわれ，その普及段階に至って他部落と の農家とも行なわれるようになってきた2).しかし， 大潟町では, 発生当初から大部分が他部落の農家と の間で行なわれ，しかもそれが「浜」農家の委託・ 「在」農家の受託という明瞭な地域分化をみせてい ることを特徵とする(第 1 表).

この現象を分析するには，両地域の農業生産にお ける地域的差異を明らかにする必要がある。「浜」と 「在」では, 農業生産の諸要素において差が大きい. まず水田面積で大きい差がみられる.「浜」農家の 1 戸当たり面積は $30 \mathrm{a}$ にすぎないが，「在」農家は144 a で，「浜」の 4.8 倍にもなる. そのうえ「浜」農家 の水田は, 「在」地区や頸城村にあり, $2 \sim 3 \mathrm{~km}$ の通 作距離は通常のことで，作業・管理労働に不便をか 
第 1 表 地域別受委託状況

\begin{tabular}{|c|c|c|c|c|}
\hline \multirow{2}{*}{$\begin{array}{l}\text { 地 } \\
\text { 域 } \\
\text { 別 }\end{array}$} & 委 & 託 & 受 & 託 \\
\hline & 戸 $(\%)$ & 面積(a)(\%) & 戸 $(\%)$ & 面積(a)(\%) \\
\hline 浜 & $\begin{array}{r}86 \\
(91.5)\end{array}$ & $\begin{array}{l}2,006 \\
(97.0)\end{array}$ & $\begin{array}{c}23 \\
(25.8)\end{array}$ & $\begin{array}{c}418 \\
(20.8)\end{array}$ \\
\hline 在 & $\begin{array}{c}8 \\
(8.5)\end{array}$ & $\begin{array}{c}64 \\
(3.0)\end{array}$ & $\begin{array}{r}66 \\
(72.4)\end{array}$ & $\begin{array}{l}1,592 \\
(79.2)\end{array}$ \\
\hline 計 & $\begin{array}{r}94 \\
(100.0)\end{array}$ & $\begin{array}{c}2,130 \\
(100.0)\end{array}$ & $\begin{array}{c}89 \\
(100.0)\end{array}$ & $\begin{array}{c}2,010 \\
(100.0)\end{array}$ \\
\hline
\end{tabular}

(新潟県農林部(1968)「昭和43年度農業動向調查報告書」により作成).

こっている．畑面積では，砂丘地に立地する「浜」 諸集落の農家が, 畑地総面積の $84.3 \%$ 占めるが, 1 戸当たりでは $13 \mathrm{a}$ にすぎない，一方，水田地域の 「在」は $12 \mathrm{a}$ で，両地域の間にはほとんど差がない， このような耕地面積，とくに水田面積の差が基本的 に両地域における農業経営のあり方を規定し，また 兼業の進行にも差異をつくりだす要因となっている 昭和35年時点で，すでに「浜」集落では著しく兼 業が進行していた(「浜」：專業5.4\%，1 兼 25.2\%， 2 兼 $69.4 \%$ ，「在」: $37,2 \%, 50.2 \%, 12.6 \%)$.その 兼業内容は，主として直江津地区にある工場の工員 と，その時点ではまだかなり存在していた出稼や人 夫・日雇からなっていた。つまり，この時点では， 直江津地区の諸工場は，昭和初期以降，大潟町を含 む周辺町村の農村労働力を吸引してきたのであった が，まだ出稼や人夫・日㕍を減少せしめるほどのも のではなかったのである.

昭和 30 年代中頃から 40 年代前半までの 10 年間に, 植江津地区の信越化学, 日本ステンレス等の工場拡 張, 関連・下請・子会社の設立, 三菱化成アルミエ 場の進出，さらに大潟町への帝国石油，第一工業製 薬等の進出(佐藤, 1977)によって地域労働市場が拡 大した. 40 年には「浜」の 2 兼農家率は $88 \%$ に達し， 「在」も $20 \%$ に近づいた. 出稼, 人夫・日雇が減少 し, 恒常的兼業が増加した. とくに「浜」で安定兼 業が強まった。

第 2 表は基幹的農業従事者の推移を示したもので
第 2 表 地域別基幹的農業従事者数の推移

\begin{tabular}{r|r|r|r|r|r|r}
\hline $\begin{array}{c}\text { 地 } \\
\text { 域 } \\
\text { 別 }\end{array}$ & 年次 & $\begin{array}{c}\text { 農家数 } \\
\text { (户) }\end{array}$ & 男(人) & $\begin{array}{c}\text { 10户当 } \\
\text { たり } \\
(\text { 人) }\end{array}$ & 女(人) & $\begin{array}{c}\text { 10户当 } \\
\text { (人) }\end{array}$ \\
\hline \multirow{4}{*}{ 在 } & 40 & 215 & 232 & 10.8 & 228 & 13.4 \\
& 45 & 214 & 249 & 11.6 & 313 & 14.6 \\
& 50 & 205 & 201 & 9.8 & 267 & 13.0 \\
\hline \multirow{4}{*}{ 浜 } & 40 & 819 & 226 & 2.8 & 830 & 10.1 \\
& 45 & 755 & 179 & 2.4 & 733 & 9.7 \\
& 50 & 629 & 189 & 3.0 & 578 & 9.2 \\
\hline
\end{tabular}

(大潟町役場, 農業委員会資料より算出).

ある.「在」は，1戸当たりほぼ 1 人の男子基幹労働 力と 1 人強の女子基幹労衝力があり， 2 人以上の基 幹学衝力が農業の担い手となっている.これに対し 「浜」は，10戸中 7 戸余りは男子基幹労衝力がいな い.これらの農家の農業の担い手は女子労働力であ る. しかし，この女子基幹労働力さえも欠落する農 家が出ている. このような農家は, 肥培管理が不十 分である゙だけでなく，自家労働力だけでは稲作が 全うできないため, 委託に出すのである.

農業機械においても「浜」の貧弱な装備と「在」 の高度な装備という明確な差異がみられる.すなわ ち「在」はトラクター（10戸当たり「在」7.9台, 「浜」0.5 台), 田植機(同 5.7 台, 0.4 台)，防除機 (同3.6台，1.5台), コンバイン(同5.7台，0.3台)， 乾燥機等が圧倒的に多く, 上層農家では稲作機械化 作業体系の完成を進めてきた. さらに，両地域の同 一耕作規模階層 (1.5 ha 以上)を対比すると, ここで も「在」の優位性がみられた。「浜」の機械装備の 低位は，耕地規模の狭小さと共に，潟川ぞいの地域 で強湿田をもち，それがごく最近まで機械利用をは ばんできたことも作用している.

このように「在」農家は「浜」農家に比べ，耕地・ 労働力・機械という農業生産の基本的要素において まさり, 反収 ${ }^{4)}$ と作業能率において優位性を確立し てきたのであった．とくに機械を装備した上層農家 は「これまでにない強い規模拡大要求をもつ」(伊藤, 
第 3 表 経営耕地規模別農家数の増減

\begin{tabular}{|c|c|c|c|c|c|c|c|c|c|c|c|c|c|}
\hline $\begin{array}{l}\text { 地 } \\
\text { 域 } \\
\text { 別 }\end{array}$ & 次 & $\begin{array}{l}\text { 農 } \\
\text { 家 } \\
\text { 数 }\end{array}$ & $\begin{array}{l}\text { 例 } \\
\text { 外 } \\
\text { 規 } \\
\text { 定 }\end{array}$ & $\begin{array}{c}0.1 \\
2 \\
0.3\end{array}$ & $\begin{array}{c}0.3 \\
i \\
0.5\end{array}$ & $\begin{array}{l}0.5 \\
i \\
0.7\end{array}$ & $\begin{array}{l}0.7 \\
i \\
1.0\end{array}$ & $\begin{array}{l}1.0 \\
i \\
1.5\end{array}$ & $\begin{array}{l}1.5 \\
2.0 \\
2.0\end{array}$ & $\begin{array}{l}2.0 \\
i \\
2.5\end{array}$ & $\begin{array}{c}2.5 \\
i \\
3.0\end{array}$ & $\begin{array}{l}3.0 \\
i \\
5.0\end{array}$ & $\begin{array}{l}\text { 5. } 0 \\
\text { 上 } \\
\text { 上 }\end{array}$ \\
\hline \multirow{3}{*}{ 在 } & 40 & 215 & • & $\begin{array}{c}11 \\
(5.1)\end{array}$ & $\begin{array}{c}11 \\
(5.1)\end{array}$ & $\begin{array}{c}11 \\
(5.1)\end{array}$ & $\begin{array}{r}15 \\
(7.0)\end{array}$ & $\begin{array}{c}38 \\
(17.7)\end{array}$ & $\begin{array}{c}56 \\
(26.1)\end{array}$ & $\begin{array}{c}57 \\
(26.5)\end{array}$ & $\begin{array}{c}13 \\
(6.0)\end{array}$ & $\begin{array}{r}3 \\
(1.4)\end{array}$ & - \\
\hline & 45 & 214 & - & $\begin{array}{c}12 \\
(5.6)\end{array}$ & $\begin{array}{r}15 \\
(7.0)\end{array}$ & $\begin{array}{c}8 \\
(3.8)\end{array}$ & $\begin{array}{c}13 \\
(6.0)\end{array}$ & $\begin{array}{c}29 \\
(13.6)\end{array}$ & $\begin{array}{c}54 \\
(25.2)\end{array}$ & $\begin{array}{r}55 \\
(25.7)\end{array}$ & $\begin{array}{c}21 \\
(9.8)\end{array}$ & $\begin{array}{c}7 \\
(3.3)\end{array}$ & • \\
\hline & 50 & 205 & • & $\begin{array}{c}10 \\
(4.9)\end{array}$ & $\begin{array}{c}10 \\
(4.9)\end{array}$ & $\begin{array}{c}6 \\
(2.9)\end{array}$ & $\begin{array}{c}16 \\
(7.8)\end{array}$ & $\begin{array}{c}30 \\
(14.6)\end{array}$ & $\begin{array}{r}45 \\
(22.0)\end{array}$ & $\begin{array}{c}42 \\
(20.5)\end{array}$ & $\begin{array}{c}21 \\
(10.2)\end{array}$ & $\begin{array}{c}24 \\
(11.7)\end{array}$ & $\left(0 . \frac{1}{5}\right)$ \\
\hline \multirow{3}{*}{ 浜 } & 40 & 819 & $\begin{array}{c}3 \\
(0.4)\end{array}$ & $\begin{array}{r}207 \\
(25.3)\end{array}$ & $\begin{array}{c}224 \\
(27.3)\end{array}$ & $\begin{array}{c}180 \\
(22.0)\end{array}$ & $\begin{array}{c}132 \\
(16.1)\end{array}$ & $\begin{array}{c}54 \\
(6.6)\end{array}$ & $\begin{array}{c}17 \\
(2.1)\end{array}$ & $\begin{array}{r}1 \\
(0.1)\end{array}$ & $\bullet$ & $\begin{array}{r}1 \\
(0.1)\end{array}$ & • \\
\hline & 45 & 755 & $\begin{array}{r}3 \\
(0.4)\end{array}$ & $\begin{array}{c}192 \\
(25.4)\end{array}$ & $\begin{array}{c}218 \\
(28.9)\end{array}$ & $\begin{array}{c}162 \\
(21.5)\end{array}$ & $\begin{array}{c}104 \\
(13.8)\end{array}$ & $\begin{array}{c}60 \\
(7.9)\end{array}$ & $\begin{array}{c}13 \\
(1.7)\end{array}$ & $\begin{array}{c}2 \\
(0.3)\end{array}$ & $\begin{array}{r}1 \\
(0.1)\end{array}$ & • & • \\
\hline & 50 & 629 & $\begin{array}{r}2 \\
(0.3)\end{array}$ & $\begin{array}{c}181 \\
(26.2)\end{array}$ & $\begin{array}{c}211 \\
(30.5)\end{array}$ & $\begin{array}{c}154 \\
(22.3)\end{array}$ & $\begin{array}{r}89 \\
(12.9)\end{array}$ & $\begin{array}{c}39 \\
(5.6)\end{array}$ & $\begin{array}{c}12 \\
(1.7)\end{array}$ & $\begin{array}{r}3 \\
(0.4)\end{array}$ & $\left(\begin{array}{c}1 \\
(0.1)\end{array}\right.$ & . & • \\
\hline
\end{tabular}

(大潟町産業課扣よび農業委員会資料より集計・算出).

1979)ことになった．しかし，土地売買は昭和 38 年 以降減少してきた．以上が，大潟町の請負耕作にお ける「浜」農家の委託，「在」農家の受託をつくりだ した基本要因である.

次に，両地域のどの階層が委託し，どの階層が受 託するかを明らかにする. そのための手がかりを第 3 表に示した耕地規模別農家数増減の分岐点（ここ では，一応「階層分解基軸」といえよう）に求める. 第 3 表のように「分解基軸」は「在」で $2.5 \mathrm{ha}$, 「浜」 では 2 ha の線である．この「基軸」以上の農家層 を規模拡大農家とみると，「浜」における極端な僅 少 (2ha 以上 4 戸， $0.6 \%)$ と逆に「在」に打ける多 数の存在 $(2.5 \mathrm{ha}$ 以上 46 戸 $22.4 \%)$ 扰よび増加，と くに 3 5 ha 層の増加, さらには 5 ha 以上層の発生, そして「浜」の下層零細農家の著しい滞留(例えば 1 ha 以下 $92 \%)$ が指摘できる.ここに,「浜」の下層 零細農家の「在」上層農家への委託＝「在」の上層 農家の「浜」下層零細農家からの受託という関係が 形成される地域的・階層的基盤があったといえよう。

\section{IV 地域労働市場の展開と委託農家の形成}

大潟町の請負耕作は, 昭和 $37 \cdot 38$ 年頃と昭和 $47 \cdot$ 48年頃の二つの時期に増加を強めてきたとみられる. 第 1 章で述べた理由から公式の統計数字はないが,
県農林部の「請負耕作市町村別調査」(昭和 42 年)に よると，大潟町で請負耕作がはじまったのは昭和 35. 年頃で,「請負耕作関係農家の最も多い年(発生でな く累積)」は昭和38年であった. また昭和 $47 \cdot 48$ 年に ついては, 関係者の話では, 「減反」開始 $2 \sim 3$ 年後 に再び増加しはじめたという.

請負耕作のこうした増加動向を地域労働市場の展 開という側面から解明する.すでにみたように「浜」 農家の中には農業生産にとって必要な基幹労働力ま でも農外に流出し，それの欠落する農家がみられた。 また直江津地区，大潟町への工場進出によって農家 の「人手不足は深刻」(佐藤，1977)になった。この ことは, 農家労働力の流出が地域労働市場の展開 (性格と規模)に規定されることを示している5)。し たがって, また委託農家の形成も地域労働市場の展 開に規定されるところが大きいといえる。

地域労働市場の展開をみる手がかりとして，まず 大潟町の就業状況を調べた．昭和52年の就業者は約 5,000 人, このうち町内諸企業勤務者と農業, 商工 業自営業者が 3,000 人強で, 町外諸企業への通勤者 が 1,900 人強である. 町外諸企業への通勤者の 60.5 . $\%(1,176$ 人)を占める上越市は, 大潟町にとってきわ めて大きい労働力需要地である (町外就業者数は次 のとおり：上越市 1,176 人 $60.5 \%$ ，頸城村 325 人 16.7 
$\%$, 柿崎町 69 人 $3.6 \%$, 柏崎市 25 人 $1.8 \%$, 吉川町 11 人 $0.6 \%$, 東頸城郡 3 人 $0.2 \%$ ，その他の市町村 324 人 $16.7 \%)$. また, 大潟町自体も大きい労㗢力需要 地である.すなわち, 他市町村からの通勤者が1,900 人を超え, また大潟町全就業者 3,000 人強のうち, 賃労働者は 1,100 人程度とみられ ${ }^{6)}$, 上越市に匹敵す る労働力需要地である.

この上越市と大潟町の二つの労働市場の形成と展 開(規模と性格)は，なによりもこの地域の工業発展 にかかわっている. 上越市直江津地区の信越化学, 日本ステンレス，日曹製鋼の大工場（当該地域とし て）は大正末・昭和初期に，豊富低廉な電力と零細 農民の過剩労働力に依存して設立され, 発展してき た.ここでの労働は高温とホコリの中での長時間の 苛酷な重労働であっだ).そこでは, 壮健で忍耐力 のある男子労働力が雇われたのであった.

昭和 30 年代前半まで，大潟町の農民にとって直江 津地区のこれら 3 大工場とその関連・下請工場8)の 現場が唯一の地元労働市場であって，そこに主とし て「浜」の零細農民が吸引されたのであった，しか し，まだまだ杜氏などの出稼，人夫・日雇，転出就 職が多かったことを考えると，直江津地区の労働市 場は雇用規模が大きく，雇用条件がよかったとはい えないのである.

「天然ガス・ブーム」と「高度成長」期の重合と いう好条件が昭和 $35 \sim 45$ 年に, 大潟町への第一工業 製薬や帝国石油，直江津地区での三菱化成アルミエ 場の進出, さらに信越化学, 日本ステンレス等既設 工場の拡張と技術革新を進め，また直江津地区や大 潟町に関連・下請・子社会の設立を促した。こうし た工場の新設之拡張は求人をふやした.しかし，化 学・装置工業である信越化学, 三菱化成, 第一工業 製薬，技術革新を進めた日本ステンレス，信越化学 等の主要工場は新規学卒者・若年層の工員採用が中 心であった ${ }^{99}$. 中小企業は新規学卒者・若年層の採 用が不可能となり,「工員引き抜き」も行なわれ,
ここでの労働力不足はとくに深刻となった．比較的 年齢の高い既就業者・農民の工員採用が続き, 婦 人の貨労働化も進んだ.この労働力吸引過程で出稼 や人夫・日雇の不安定兼業の減少, 恒常的賃労働の 増加が進み ${ }^{10)}$, 雇用条件も相対的にではあるが，安 定度を高めた(佐藤，1977)。 その結果，前述のよう に委託農家が増加したのであった。

昭和 40 年代後半にはいると直江津地区で労働力需 要の停滞がみられはじめた。 それは電力事情の悪 化 ${ }^{11)}$, 天然ガス採掘量の激減等 ${ }^{12)}$ による有利な立地 条件の喪失, 技術革新による企業の表日本指向 ${ }^{13)}$, 新鋭機械・施設の設置による人員の削減などによる ものであった：さらに石油ショック(昭和 48 年)，そ れに続く「低成長」時代への突入によって雇用差し 控え, 配転, 出向, 退職勧告も強められた. その反 面, 第 3 次産業の雇用増がこれをカバーしてきた.

こうした動きの中で大潟町への丸大八ム（設立昭 和46年, 従業員 320 人(昭和 50 年度)), 大潟ブルボン (設立昭和 47 年, 従業員 620 人(昭和 50 年度)) 等食品 工場の進出は婦人労㗢力の需要を高め, 農家の主婦 労働力を大量に吸引し, 主婦の農業従事者を減少せ しめた (女子農業専従者についてみると, 昭和 45 50 年の間に「在」で 46 人減,「浜」で 155 人減).こ うした主婦の農業従事者の農外就労が，昭和 $47 \cdot 48$ 年における委託農家の発生に大きい役割を果たした. なお，委託移行における主婦の役割は次節以下で述 べる.

\section{V「浜」・犀潟部落農家の兼業深化と委託}

大潟町の最南西端に位置し, 直江津地区に隣接す る「浜」集落の犀潟部落は, 工場進出が早く, 当然 兼業化も早かった. そのため, 下層零細農家の滞留 も著しい ${ }^{14)}$. 昭和50年時点で, 農外就労 (常時勤務) 者の出ていない農家は 97 户中 4 戸にすぎず(それむ 自営兼業), 専業農家は 1 户もない(15). 世帯主・長 男いずれかの常勤者を出す農家は97戸中 82 戸，その 
第 4 表 犀潟部落における常勤者の続柄別，人数別戸数と委託農家数(昭和 50 年)

\begin{tabular}{|c|c|c|c|c|c|c|c|c|c|c|c|c|}
\hline & 1 & & 人 & 2 & & 人 & 3 & & 人 & そ & の & \\
\hline & & 戸数 & 委託 & & 戸数 & 委託 & & 戸数 & 委託 & & & 数託 \\
\hline 続柄別 & $\begin{array}{l}\text { 主 } \\
\text { 長男 } \\
\text { その他 }\end{array}$ & $\begin{array}{r}17 \\
8 \\
9\end{array}$ & $\begin{array}{l}5 \\
3 \\
1\end{array}$ & $\begin{array}{l}\text { 主夫婦 } \\
\text { 長男夫婦 } \\
\text { 主・長男 } \\
\text { 主・その他 } \\
\text { 長男・その他 } \\
\text { その他 }\end{array}$ & $\begin{array}{r}18 \\
11 \\
4 \\
6 \\
3 \\
1\end{array}$ & $\begin{array}{l}5 \\
5 \\
2 \\
3\end{array}$ & $\begin{array}{l}\text { 主夫婦・長男 } \\
\text { 主夫婦・その他 } \\
\text { 主・長男夫婦 } \\
\text { 主・長男・その他 } \\
\text { 長男・その他 }\end{array}$ & $\begin{array}{l}1 \\
3 \\
4 \\
3 \\
1\end{array}$ & $\begin{array}{l}3 \\
2 \\
2\end{array}$ & $\begin{array}{l}\text { 主夫婦(自営) } \\
\text { 主夫婦(自営) } \\
\text { 主夫婦(自営) } \\
\text { 主(漁業) }\end{array}$ & $\begin{array}{l}\text { ・長男 (勤務) } \\
\text { ・ その他 (勤務) }\end{array}$ & $\begin{array}{l}3 \\
1 \\
3 \\
1\end{array}$ \\
\hline 合 計 & & 34 & $\begin{array}{c}9 \\
26.5)\end{array}$ & & & $\begin{array}{r}15 \\
(34.9)\end{array}$ & & & $\begin{array}{r}7 \\
(58.3)\end{array}$ & & & 8 \\
\hline
\end{tabular}

（ ）内委託農家率。単位\%.

(農家台帳, 1 部ききとりにより作成).

どちらかを含めて 2 人以上が 42 戸 3 人が 12 戸であ る(第 4 表)。世帯主・長男だけでなく主婦の農外就 労も多小(主婦常勤者 38 人, 自営業従事者 7 人(第 4 表)).こうした著しい賃労働化・農業労働力の堮失 が高い委託農家率 $(39.2 \%)^{16)}$ をつりだした原因で ある. また，このことは常勤者が多いほど委託農家 率が高い(第 4 表参照)ことからもいえるのである.

世帯主や長男の恒常的賃労働化は委託農家形成の 基礎条件である. しかし，それが直接契機となるこ とは少なく，とくに若い長男の場合はほとんどない， 第 4 表に示した「常勤者」「1人」の委託農家は妻死 亡・病弱 $\rightarrow$ 委託 ( 2 例), 父親死亡 $\rightarrow$ 委託，あとつぎ なし，女世帯，小家族世帯という特殊事情をもつ農 家であった. 一般に世帯主が常勤の場合でも，主婦 を中心に世帯主の休日あるいは朝晚の農作業援助， 機械力の導入，部分作業委託によって，たとえ経営 を粗放化しても稲作は続けようとするのである.

犀潟部落では，耕地規模の大小が委託農家形成の 規定要因とはなっていない，それは「分解基軸」以 下の農家だけしか存在せず17)，しかも大多数の農家 が世帯主や長男を常勤者とする場合, 経営委託に出 すか,「自作」(「非委託」)を維持するかの決定要因は, 耕地規模の大小にあるのではなく18)，とくに主婦が 農業に従事するか，農外労働に従事するかにかかっ ているからである．第 5 表に委託・非委託農家にお ける主婦の農業従事者数と常勤者数を示した．それ
第 5 表犀潟部落における委託農家・非委託農家 の主婦の農業従事者数と常勤数の状況

(昭和 50 年)

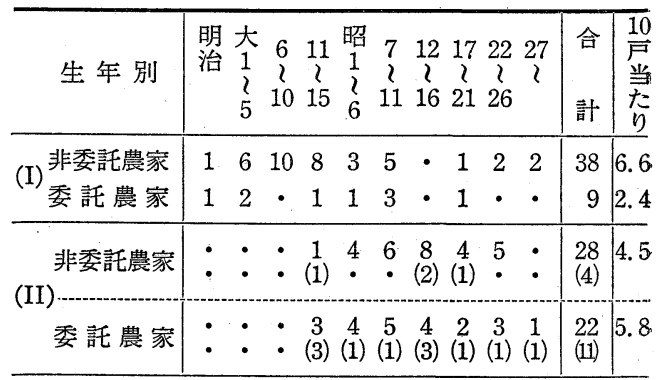

(I)：農業だけに従事した者 (II) : 常勤者.

ただし( )は農業にまったく従事しない者.

(農家台棖, 1 部ききとりにより作成).

によると, 農家の主婦(長男の嫁を含む)は過半数が 常勤者である. その年齢は「農業だけに従事した 者」より若い。また委託農家の主婦は 31 人中 22 人 (71\%)が常勤者であり，農業にまったく従事しない 者も多い $(50 \%)$ ，これらの点から，後節でも述べる ように主婦の農外労働彷事が委託移行に大きな役割 を果たしているといえる. 主婦が農業に従事する場 合, 多くは世帯主も，たとえ少日数でも，主として 機械操作や重作業にあたり，「自作」(「非委託」)を維 持する. しかし，農業従事の主婦は高齢者であり， リタイヤーは間近かに迫っている.

犀潟部落農家の主婦労働力は「浜」に工場が進出 するまで雇用機会に恵まれず，「在」農家の農業日 雇に多く出ていたのであった．昭和35～45年の中小 零細工場の設立，とくに昭和 $46 \bullet 47$ 年の食品工場の 
進出は，農家主婦労働力の吸引を強めたのであった. 犀潟部落農家の主婦は, 下請・子会社・中小零細工 場と食品工場の工員が多い, そして, 勤務先は部落 内か町内で, 通勤時間を要しない職場である ${ }^{19)}$.

大潟町における(そして犀潟部落においても), 主 婦労働力雇用の典型は食品工場である. 大潟ブルボ ンでは従業員620人の $60 \%$ ，丸大食品は 320 人の $90 \%$ を婦人が占め, その中で 45 歳以上が前者で $9 \%$, 後 者では $22 \%$ むる(昭和 52 年). 大潟ブルボンの雇用 形態は常雇・臨時雇・パートの 3 形態で, 労働時間 は常雇と臨時雇が 8 時間, パートが 5.5 時間となっ ている. 臨時雇とパートが全従業員の 3 分の 1 を占 め, ほとんど主婦である. 常雇は年間就労, 臨時雇 は季節就労であり，共に日給月給制をとっている. パートは自分の都合のよい就労時間を選んで働くこ とができ，これは時間給である. 丸大食品は形式的 には全員常雇とされているが，女子工員は全員時間 給で, この点では臨時雇と変わらない，女子従業員 の大部分は工員で, 各自の希望によって労働時間 (6・7・8 時間の 3 種類) を選ぶことができる.

大潟町の主婦労働市場は, 食品工場の進出によっ て一気に拡大した，それにしても，そこに吸引され る近隣諸集落(犀潟部落も含む)の農家主婦労働力は, その労働力の販売にあたって,「不熟練労働力」,

「家計補助的労働力」,「低貨金」「「臨時工」,「不安 定」という主婦労働力雇用の一般的性格を超えるも のではなく，さらに農家の主婦という立場から家 事・育児, 農作業, 兼業という「 3 重労働」の重荷 を背負わされるのである. そのゆえに，たとえ不安 定な雇用条件であっても, 工場勤務を続けるために は「 3 重労働」の負担軽減が要請され, その対象と して農業が切り落されたのであった. 主婦労働市場 の展開は, 委託農家の発生においてかかる意味内容 をもつ規定要因であった.

\section{VI 絽営委託への「段階的移行」}

まず，「自作」農家がどのような経緯をとって経 営委託農家となったかを以下の事例で考察する(第 2 図参照).

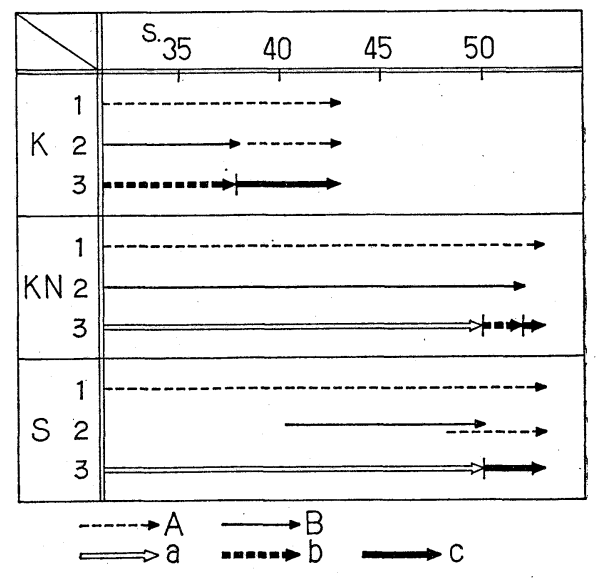

第 2 図委託の段階的移行

1. 世帯主 2. 同妻 3. 経営形態.

$\mathrm{A}$ : 常時勤務 $\mathrm{B}$ : 農業従事 $\mathrm{a}$ : 自作 $\mathrm{b}$ ：作業委託 $\mathrm{c}:$ 経営委託.

( $\mathrm{K}$ : 新潟県農林部 :「昭和 43 年度農業動向調查報告蓄」, $\mathrm{KN}$, $\mathrm{S}$ :ききとり (昭和 35 年)により作成).

事例 I ：K氏は「浜」の雑貨商で，60 a の水田を もっていた. 水田耕作の担い手は主婦であった. 耕 耘機などの機械は一切なく，賃耕や手間替にたよっ てきた. 昭和 35 年以降, 工場進出・人口增加にとも なって商売が多忙となった. 主婦も商売に尃念する ため，昭和38年から水田を全部委託した．相手方は 親戚(形城村)と「在」の知人であった.

事例 $I ： \mathrm{KN}$ 氏(浜)は $62 \mathrm{a}$ の水田と $20 \mathrm{a}$ 程度の畑 をもち，農業と人夫・日雇に従事してきた，昭和 30 年に国鉄「保線区」に就職した。これによって農業 の担い手は主婦に移った。しかし，休日には農作業 に従事し, 農繁期には休㗇をとった. 36 年と 40 年に 転職したが，農作業従事の状態は変わらなかった。

耕耘機, 脱穀機, 乾燥機など一応最少限の機械を所 有した.こどもは女だけであった，あとつぎの 2 女 は市立病院の助産婦, 養子は会社員で共に農業の経 験はなく，将来農業をやる意志もない. 50 年に孫が 生れ，手がかかるようになったこと，世帯主の血圧 が高くなったことをおもな理由とし，機械作業部分 
を「在」の農家に委託した。52年から全面委託をは ビめた.

事例III：S 氏(浜)は義務教育終了と同時に，少年 エとして信越化学に就職した．昭和40年に結婚した 時点で，水田は $32 \mathrm{a}$ ，畑は $10 \mathrm{a}$ 強であった．その面 積は今も変わらない，耕作は主婦の手にまかされて きた，機械はまったくもたず，ほとんど手作業でや ってきた．脱穀・調整だけ外部労働に依存した４8 年から主婦も年間を通して丸大食品に働きに出るよ うになった。しかし；農業はこれまで通り続けた。 こうした「 3 重労㗢」の過労が，49年暮の大病の原 因であった．主婦の病気を契機に全面委託に出した 相手は「在」農家で，その農家の若い後継者の農業 熱心さにほれこんで委託したという.

すでに「自作」から委託への移行は，男子基幹労 働力の農外就労・農業離脱が基礎条件であり, 主婦 の農業離脱が多くの場合，委託移行の直接的契機と なることを指摘した：これらの事例でもそれがみら れた．委託移行過程において，世帯主と主婦の役割 が異なり, まず世帯主の農外就労が先行する. それ は男子労働市場と主婦労働市場の規模と性格の差, 家庭における主婦の特殊な立場のためである，世帯 主の農外勤務が経営委託に直結することは稀である。 主婦を中心に「自作」が維持されるからである.し かし, やがて部分作業委託や水田の一部の経営委託 がはじまる. それでも主婦を中心に耕作が維持され る. 水田の全部を委託するのは主婦の農外勤務・農

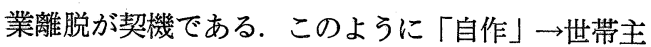
の勤務 $\rightarrow$ 主婦中心の耕作 $\rightarrow 「$ 作業委託」・主婦の勤 務 $\rightarrow 「$ 経営委託」というょうに「段階的移行」過程 をとって委託が進行するのである.

\section{VII 町外農家への委託の増加}

大潟町の委託農家は昭和 42 年当時に比べると, 近 年ではいっそう増加しているとみられる，それは， 「浜」に打ける持続的增加と「在」に扔ける近年の
急速な増加の結果である. 昭和42年以降の調査がな いため，実数の把握はできないが，例えば昭和50年 に犀潟部落の委託農家率が40\%弱に達していたこと から，「浜」全体で 200 250戸の委託農家があると 推定される. 昭和 42 年調査で「在」の委託農家は 8 戸にすぎなかったが, 近年, 「在」の和泉, 高橋部落 でもふえてきたままた昭和 42 年当時, 町外農家への 委託は 5 戸であったが，今日ではその数は多くてつ かめないという (大潟町役場)。このように大潟町で は，近年，委託が「浜」農家だけでなく，「在」農 家でも発生してきた. そして, その土地を町内の 「在」農家だけでなく, 町外の頸城村, 吉川町の農 家が受託するようになってきたのである.

町外農家への委託増加は二つの理由による. まず， 大潟町南西部の犀潟，渋柿浜等の「浜」部落は潟川 ぞいに水田が多く20)，しかも頸城村内にかなりの面 積年をを占めることに由来する. これら町外にある水 田はこれまでの経緯22)から，䁰城村の農家に委託す る場合が多い，次に，委託料の問題がある．今日， 大潟町の地域別受委託関係は，おおおかに(1)「浜」の 委託 $\rightarrow\lceil$ 在」(潟田, 蜘ヶ池, 長崎, 吉崎)の受託, (2)「浜」 の委託 $\rightarrow$ 頸城村の受託, (3)「在」(高橋, 和泉等)の委

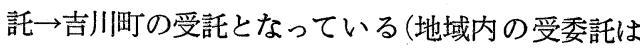
省略).「浜」では「供給」(委託) $>$ 「需要」(受託)の関 係が成立している，それゆえ，同一町内で「浜」に 近く，賃耕や作業受委託で結びつきのある「在」に 委託する傾向が強い.(1)の場合でも「供給」>「需 要」の関係があり, 委託料は $2.5 \sim 3$ 俵である. (3) の場合では「供給」く「需要」の関係がみられる.す なわち, 吉川町では労働市場が未展開のため委託農 家が少ない，しかし，大潟町に近い部落では，積極 的に受託する農家があり，これらが大潟町の水田を 受託しょうと期待しているからである.ここでの委 託料は 4 俵である.(2)の場合では，(1)にみられる 「供給」〉需要」の関係はうすれるが，(3)に比べれ ば，上越市や大潟町内および自村内に労働市場が開 
かれているため, 委託供給が多く, ここでの委託料 は 3.5 俵程度である. 3 地域の中で「在」農家(潟田， 蜘ヶ池，長崎，吉崎）の委託料は吉川町, 頸城村の 農家のそれよりも低い。これが町外農家への委託流 出 ${ }^{233}$ の加速と委託料の高位平準化傾向の原因となっ ており，「在」の委託料も上昇気味といわれる ${ }^{24)}$. こうした町外農家への委託流出, 委託料の上昇傾向 が「在」の受託農家に危機感を抱かせ, 新しい動き 一組織化一をとらしめたのであった。

\section{VIII 受託農家の性格と耕作規模拡大過程}

\section{1）受託農家の性格}

大潟町の請負耕作は,「浜」の委託・「在」の受託 に特徵があった．潟田部落は「在」の諸部落中最も 耕地規模・家族労働力・機械装備がすぐれ，受託面 積も大きかった，とくに若い経営主, 後継者は規模 拡大に意欲的であった. 受託農家の典型は，この部 落の上層農家にみられる.

潟田部落は14戸からなる「在」の水田集落である. 14戸の農家は所有耕地規模, 受託地の有無と規模, 家族員の就業状況，農業後継者の有無，機械の装備
状況から上位 7 戸と下位 7 戸に分類できる(第 6 表). 下位 $8 \sim 14$ 番農家は水田が 2 ha 以下で, 11 番農家 を除いて受託はなく, 男子基幹労働力は貨労㗢に従 事し，農業後継者はいない，機械もまったくないか， 貧弱である. 主婦の労働が農業経営を支え, 最下層 ではそれさえも勤務の合間になされているのであっ て，経営委託への前段階にあるといえる.

$1 \sim 7$ 番農家は $2 \mathrm{ha}$ 以上の水田を所有し，さらに 全戸受託している．青壮年層よりなる農業基幹労働 力 2 人以上，うち男子 1 人以上というすぐれた家族 労働力と中型トラクター・育苗施設・田植機・防除 機・自脱コンバイン・乾燥施設という基本的な機械 を装備することによって，「稲作中型技術体系」(伊 藤，1979）を完成している.このグルーブはさらに 二つに分けられる. $3 ， 7$ 番農家は後継者が役場勤め であるが，世帯主が50歳前後で壮健なため，現在の ところ長男の就職が経営維持に支障をきたしていな い.しかし，受託は少なく，最近はふえていない。 経営規模拡大の意志は失せている. 他の 5 戸 $(1,2$, $4,5,6$ 番農家) は受託が $2 \sim 4$ ha，総水田耕作面積で 4 8 ha になる. 農業所得による家計充足率は 90〜

第 6 表 潟田部落農家の概要

\begin{tabular}{|c|c|c|c|c|c|c|c|c|c|c|c|c|c|}
\hline $\begin{array}{l}\text { 農 } \\
\text { 家 } \\
\text { 番 } \\
\text { 号 }\end{array}$ & $\begin{array}{l}\text { 乺 } \\
\text { 有 } \\
\text { 水 } \\
\text { (a) }\end{array}$ & $\begin{array}{l}\text { 所 } \\
\text { 有 } \\
\text { 畑 } \\
\text { (a) }\end{array}$ & $\begin{array}{l}\text { 受 } \\
\text { 詆 } \\
\text { 水 } \\
\text { (a) } \\
\text { (a) }\end{array}$ & $\begin{array}{l}\text { 農業従事 } \\
\text { （博従） }\end{array}$ & $\begin{array}{l}\text { 農外労働従事 } \\
\text { (*本雇・常勤) }\end{array}$ & $\begin{array}{l}\text { 継 } \\
\text { 者 }\end{array}$ & $\begin{array}{l}\text { 耕 } \\
\text { 耘 } \\
\text { 機 }\end{array}$ & $\begin{array}{l}\text { 1 } \\
\text { ज } \\
\text { 夕 } \\
\text { I }\end{array}$ & $\begin{array}{l}\text { 防 } \\
\text { 除 } \\
\text { 機 }\end{array}$ & $\begin{array}{l}\text { バ } \\
1 \\
y \\
37 \\
1\end{array}$ & $\begin{array}{l}コ \\
\text { バ } \\
\text { イ } \\
\text { ン }\end{array}$ & $\begin{array}{l}\text { 田 } \\
\text { 植 } \\
\text { 機 }\end{array}$ & $\begin{array}{l}\text { 乾 } \\
\text { 燥 } \\
\text { 機 }\end{array}$ \\
\hline 1 & 420 & 8 & 400 & 主†妻 長男悽† & & O & O & 0 & $\bigcirc$ & $\times$ & $\bigcirc$ & $\bigcirc$ & 0 \\
\hline 2 & 341 & 17 & 210 & 主†妻†母 & 弟*弟* & O & 0 & 0 & 0 & $x$ & 0 & 0 & 0 \\
\hline 3 & 290 & 12 & 70 & 主悽† & 長男* 3 女* & $x$ & $x$ & 0 & 0 & $\times$ & 0 & 0 & 0 \\
\hline 4 & 280 & 10 & 320 & 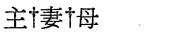 & 弟* ～～～ & 0 & 0 & 0 & 0 & $x$ & 0 & 0 & 0 \\
\hline 5 & 273 & 23 & 130 & 主†妻† & 3 女* & $\triangle$ & 0 & 0 & 0 & 0 & 0 & 0 & 0 \\
\hline 6 & 240 & 9 & 200 & 主悽㕮 & & $\triangle$ & 0 & 0 & 0 & 0 & 0 & 0 & 0 \\
\hline 7 & 200 & 12 & 100 & 主†妻† & 長男* 2 男* & $x$ & $x$ & 0 & 0 & $x$ & 0 & 0 & 0 \\
\hline 8 & 179 & 13 & & 主 妻† & 主* & $\times$ & $x$ & 0 & 0 & $\times$ & 0 & 0 & 0 \\
\hline 9 & 125 & 12 & & 主 妻† & 主*長男* ～ & $x$ & 0 & $\times$ & $x$ & $x$ & $x$ & $x$ & $\times$ \\
\hline 10 & 110 & 4 & & 主 妻† & 主 2 男* 3 女* 4 女* & $x$ & 0 & 0 & $x$ & 0 & $x$ & 0 & $x$ \\
\hline 11 & 74 & 5 & 20 & 妻† & 主*妻 長女*2女 & $x$ & 0 & 0 & $x$ & $x$ & 0 & $x$ & 0 \\
\hline 12 & 55 & 3 & & 主 妻† & 主 長女* & $x$ & $x$ & 0 & $x$ & 0 & $x$ & $x$ & $x$ \\
\hline 13 & 22 & 2 & & 妻 & 主*妻* & $\times$ & $x$ & $x$ & $x$ & $x$ & $x$ & $x$ & $\times$ \\
\hline 14 & 22 & 5 & & 妻 & 主*長男* 2 男* & $x$ & $x$ & $x$ & $\times$ & $x$ & $x$ & $x$ & $x$ \\
\hline
\end{tabular}

後継者 $: \bigcirc \cdots$ 農業従事 $\times \cdots$ 就職 $\triangle \cdots \cdots$ 農業従事予定. 
100\%である.これらの農家にはバイタリティに富 む若い経営者か後継者がいる.これらの経営者や後 継者こそが完成をみた「稲作中型技術体系」の担い 手であり，また若いにもかかわらず，これまで積極 的に経営規模の拡大に取り組んだ人たちだったので ある.

\section{2）受託上層農家の経営規模拡大事例25)}

前述のように受託上層農家は耕地規模が大きく， 労働力・機械力ですぐれ，規模拡大意欲が強く, バ イタリティに富む若い経営主, 後継者がいることに 共通点があった。ここにあげる事例農家は，潟田部 落の受託上層農家（農家番号 2 : 部落第 2 の耕作規 模, 水田 6.5 ha) である. この農家は土地購入と受 託によって，規模拡大を進めてきたが，それは若い 後継者 (31 歳(昭和 53 年)) の能力と 3 人以上の家族 労働力・機械力の充害にあったこの点で受託上層 農家を代表している．また後述の「受託者組合」設 立の中心的役割を果たしている点からも, 受託上層 農家を代表しているといえよう。

この事例農家は農地改革によって自作田 $160 \mathrm{a}$, 借入田 $20 \mathrm{a}$ ，畑 17 a の耕作地規模をもち，また一方 では, $40 \mathrm{a}$ の水田を貸付けていた．この農家の経営 規模拡大は昭和 35 年頃からはじまった。この時期は 「高度成長」が軌道にのり，農業基本法が制定され， この地域に工場進出がはじまり（地域労働市場の拡 大), 耕耘機導入の増加する時期でもあった.

馬耕から耕耘機耕への転換と機械乾燥（平型乾燥 機）の採用で, 必然化する耕作規模拡大の要請は, 貸付地 $40 \mathrm{a}$ の引き揚げ (昭和 25 年) と水田の購入 (昭 和 28〜 40 年 $110 \mathrm{a}$ ，ただし排水不良田で，10 a 5 6 万円の低額）を生起せしめたのであった．機械の 大型化・性能アップ (昭和 41 年 : $10 \mathrm{ps}$ トラクター, 昭和 43 年 : $13 \mathrm{ps}$ トラクター, 立型乾燥機, 生脱用 脱穀機) と長男の就農 (昭和 43 年)による家族労働力 の増強は, 昭和 35 年以降の工場進出がひきおこした 地洒上昇と売手不在によって土地購入が困難なため,
受託 (浜農家から 51 a) と養豚の拡大 (種豚 7 頭) を とらしめたのであった.

トラクターの大型化・共同化 (昭和 45 年に 4 番農 家と共同で $23 \mathrm{ps}, 15 \mathrm{ps}$ の 2 台導入) と，とくにコ ンバイン (2 条刚), 乾燥機 (18 石) の個別導入 (昭和 45 年)による秋作業機械化体系の形成は，八ザ架け に象徵されるこれまでの多労・苦汗的労働を解消し， 父親の病気入院にもかかわらず，昭和45年には「浜」 農家からの受託 1.5 ha を含めた約 4.6 ha の稲作経 営を可能とした．もっともこの年は，春秋の農繁期 に臨時雇を多く入れているが，それは，まだ主婦労 働市場が狭く，田植や収穫作業に主婦労働を容易に 雇用しえたからでもあった。

長男の結婚 (昭和46年)によって，家族労働力が増 強された。この年, 雇用依存度の最も高い田植作業 対策として田植機が導入された. 大潟町に食品工場 が進出し，主婦労㗢(雇用)の不足がみられるように なったからでもある. 家族労衔力の増強と田植機の 導入は養豚規模の拡大(水田 $17 \mathrm{a}$ を転用し, 新しい 豚舎の建設）を可能にしたのであった。最盛時の昭 和 48 年には種豚が 22 頭にもなった.

畜産の規模拡大には，稲作の省力化が要請された。 しかも丸大食品, 大潟ブルボンの工場進出が主婦労 働力を一気に，しかも大量に吸引し，農業主用労働 を得にくくしていたため，それが一層要請された。 乾燥機(昭和 47 年 : 18 石), トラクター(昭和 48 年 : $27 \mathrm{ps}$ ), 田植機(昭和 48 年 : 4 条植), コンバイン(昭 和 49 年 : 3 条刈) の導入・更新による，いわゆる「稲 作中型技術体系」の整備はその対応策であった.

昭和48年をピークに50年以降，養豚は急速に縮小 し， 53 年には種豚が 4 頭にまで減少した。一方，受 託は 50 年に新たに $150 \mathrm{a}$ ふえ，約 $350 \mathrm{a}$ となった. この時期は食品工場進出等による主婦労働市場拡大 のため農業雇用労働が得にくくなっているのである が，養豚拡張時代に導入した機械力がそれを可能と したのであった．51年には「浜」農家 2 戸の受託水 
田 $40 \mathrm{a}$ (10 a， 50 万円)，52年にも $14 \mathrm{a}$ 購入し，所 有水田面積を拡大した.

この農家の経営規模の拡大は, 基本的には, 個別 に耕地規模の拡大を図っていることにある.しかし， それが容易ではない場合, 土地を必要としない畜産 に力が注がれ, 委託の多発につれて, また飼料高に よる養豚不振の中で, その力を委託経営におきかえ た．そして地価上昇の中でも，土地購入の基本線は 貫いており，それが容易でないため受託を選んだの である. ジクザク過程をとりながらも, 規模拡大を とりえたのは，家族労働力の存在と機械力の充実で あって，同じことは他の農家にもいえるのである.

3）受託者「組合」の設立

潟田部落の上層農家 4 戸 (第 6 表, $1,2,4,6$ 農家) は, 昭和51年に「組合」を設立し，集団的受託組織 への歩みをはじめた.「組合」設立という新しい事 態は上層農家の経営規模拡大要求が土地購入によっ て満たされないだけでなく，請負耕作さえも町外農 家への委託増と委託料の上昇傾向で困難が予想され， しかも現在の耕作規模が家族労働力と機械力からみ て耕作可能規模の限界に近く，一層の規模拡大には 共同化・組織化が不可欠となっていたことにあった.

もともとこれらの農家は経営受託のほかに，以前 から個別に賃耕や作業受託を経験してきた。しかし， 個別農家による受委託は，委託者の委託申し込みに よって契約が成立するもの（受託者は「受身」の姿 勢）で，逆の場合はなかった26). しかも，それはほ とんど個人的つながりの範囲を出るものではなかっ た. それゆえにこれらの農家は組合の設立によっ て受託者集団として，農協や役場の「認知」を受け， それによって受託を容易にし, 組合への受託増を期 待したのであった．それはまた，個人では不可能な 受託の宣伝を可能としたのであっだ27.

組合の最終目標は, 経営受託等によって拡大され た大型経営で協業経営を実施することにあった。し かし，その歩みは慎重で，比較的容易な部門から手
をつけた．すなわち，共同(組合)で部分作業を受託 し，それを個人の作業消化能力に応じて配分し，個 別に実施するものであった.これは組合設立による 個人の所得減と経済的負担増を避け，旧世代層の共 同化に対する不安・危惧をぬぐうという現実的な利 点があった。

組合の活動は昭和51年冬の宣伝活動にはじまり， 52 年にはこれまでの受託のほか床土斡旋と育苗，53 年には田植の受託が追加された．52年の床土扱い高 は 48 トン ( 1 万 6,000 箱, 50 ha 分), 育苗受託は約 10 ha 分であった．53年からは育苗から田植までをセ ットとして受託するようになった．組合は共同の機 械・施設をもたず，共同作業(共同出役)も床土の取 扱いと育苗作業の一部にすぎない，個別農家で処理 できる作業は個人に配分し，それの困難な分野を共 同化している.ごく初歩的な共同化である.

大潟町には潟田部落の「組合」を除いて，水稲生 産組織はない，共同防除組織もつぶれている，潟田 部落の組合は，その点でも，また受託を目的とし最 終目標を協業経営においている点でもまったく新し い動きである.

組合の設立は若い進歩的なバイタリティに富む経 営主，後継者の存在に負うところが大きい，とくに 組織の中核となる 2 人の若い経営主は同年輩で気心 も知れ，以前に機械共同利用を経験し，また父親の 死あるいは病弱のため，いずれも若しくて経営主と なり，共に苦労して経営規模拡大を図ってきたので ある. それゆえに，彼らは委託の町外流出・委託料 上昇，そして大きくは減反という危機により敏感で あったといえる．組合設立の動きに対して関心をも つ青壮年は蜘ケ池，長崎など「在」の諸部落に数名 ずついる. 潟田の組合はこれらの青年に組織化を呼 びかけている.

\section{IX 生産調整と講負耕作}

大潟町の米生産調整は昭和46年に実施された全水 
田の約 1 割を最高に年々減少し, 昭和 51 年では単純 休耕 $5 \mathrm{ha}$ ，普通転作 $0.7 \mathrm{ha}$ にすぎない：ここに明 確な減反拒否姿勢がみられる. それには以下四つの 理由があげられる.(1)後背湿地の開拓で造成された 水田のため, 夏期の乾田化は困難で, 水稲以外に適 当な作目がなく，単純休耕しか方法を見出しえない． しかも 49年以降その補償金は打ち切りとなった。(2) 減反対象外の飯米農家が多い.(3)町議会の減反反対 決議が農家を勇気づけ，町当局の減反割当を消極的 にした（4「あまり米」でも売れるという自信をも っている.

減反政策の中で請負耕作の減少した例は多い28). しかし，大潟町ではふえている29!：それによる耕地 規模の拡大が図られている. それは，なによりも高 い水稲生産力の形成が基礎にある. かつて湛水害常 習地で反収の低かった「在」の水田も, 排水事業に より改良されて反収を上げた(5 6 俵 $\rightarrow 9 \sim 10$ 俵). さらに，それは機械の導入を容易にし，上層農家で は「稲作中型技術体系」を完成して労働生産性を高 めた.こうした技術発展の自己運動として, 当然経 営規模拡大が要請されるようになったのである.

さらに「あまり米」でも「売れる」という自信が 「受託」による耕作規模拡大姿勢をとることを可能 にしているのである. 大潟町の昭和51年度産米売渡 先は, 農協 $89.3 \%$, そのうち政府米 $87.6 \%$, 自主流 通米 $1.7 \%$ であり，業者売り (自由米)が $10.7 \%$ であ る. 農家も農協も超過米の出ることを恐れていない. それは銘柄米をもつ「自信」である(昭和 52 年度 : 越路早生 $39.2 \%$ ，コシヒカリ $13.4 \%$ )。すなち 「ヤミ米」としての「新潟産コシヒカリは, 政府買 大れ価格よりも $2 \sim 3$ 千円高く売れている」(農政シ ャーナリストの会, 1978）からである.

一方，減反政策下において，下層農家が委託を継 続あるいは選択したのは，減反補償金が必ずしも委 託料より有利でないこと, さらに単純休耕の補償金 廃止にあった，第 2 次減反(昭和 53 年から 10 年間)は,
これまで減反の対象外にあった飯米農家も減反対象 農家に入れた. そして，米作しか希望しない飯米農 家や兼業農家にも，減反によって生ずる損失を「農 協委託管理休耕」(10 a 当たり 4 万円の補償)方式を 利用すれば，補償されるという道をあけた。しかし， 大潟町の小規模零細農家は，減反より委託を選択し た. 農協委託管理休耕の場合，管理料等を差し引く と土地所有者に渡る補償金は 3 万円程度で，これは 委託料の 3 俵よりかなり低い，大潟町におけるこう した減反拒否(姿勢)は，受委託形成を増幅させるも のとなった。

\section{X あとがき}

大潟町における請負耕作の多発理由は，大量の委 託農家の発生と，これを受ける規模拡大農家の存在 に求められた。 大量の委託農家の発生は, 上越市 （直江津地区）の工業発展と大潟町への工場進出（地 域労働市場の拡大）が農業必要労働力，つまり世帯 主だけでなく主婦労衔力まで吸引し，農業経営を困 難にしたからであった. それは小規模零細農家が大 量に滞留する「浜」においてとくに顕著であり，当 然そこに大量の委託農家が発生したのであった.

受託農家は耕地規模が大きく，機械装備がすぐれ， 基幹労働力を保有する, 経営規模拡大要求の強い上 層農家であった．かかる農家は「在」に多く存在し， 「浜」ではまったく僅小であった。これが「浜」の 下層農家の委託,「在」の上層農家の受託という請 負耕作の地域的・階層的分化をつくりだした理由で あった。

委託農家の発生 (「自作」から委託への移行) は, 男子基幹労働力の農外流出を基礎条件とするが，最 終決定においては主婦の農外労働従事・農業離脱が とくに大きい役割を果たしていた。 その点, 大潟町 への食品工場進出 (主婦労働力需要の増大) は, 委託 農家の大量発生に作用した

「自作」から委託への移行は直線的でなく，「段階 
的移行」をとるものであった.ここでも委託移行に 主婦の果たす役割をみることができた．受託農家は， 労㗢力, 機械, 耕地面積で優位性をもっていた. と くに農業に積極的にとりくむ若い経営主, 後継者が 完成途上にある「稲作中型技術体系」の担い手とし て登場し, しかも，その技術発展の自己運動として それ自体が要請する経営規模の拡大を，積極的に受 けとめてきたのであった．規模拡大の基本路線は土 地購大であった。 しかし, 地価高騰, 売り手不在が 経過措置として受託をとらしめたのである.

食品工場の進出（とくに主婦労㗢市場の拡大）は 「浜」だけでなく，「在」においても委託農家をふや し，請負耕作の拡がりと深まりをみせた，その中で 町外農家への委託がふえ, 委託料の高位平準化が進 んだ、それが一部で「在」の上層・受託農家を「組 織化」させる方向に働いた，減反政策のもとで，請 負耕作による規模拡大がなされる根拠は上述の技術 問題のほかに, 銘柄米「コシヒカリ」の「売れる」 という自信であった。

賃労働化の深化と新しい機械化稲作技術の進展は, 上下層の分解を強めてきたものの, 土地流動の硬直 化現象のため貫徹できず，請負耕作が発生・展開し てきたのであった：それは農地改䩗よって打ち建 てられた「戦後自作農」の崩壊であり, 新しい一つ の経営形態の発生でもある.

$\left(\begin{array}{ll}\text { 投稿 } & 1979 \text { 年 } 6 \text { 月 } 5 \text { 日 } \\ \text { 受理 } & 1979 \text { 年10月 } 6 \text { 日 }\end{array}\right)$

\section{注}

1)このほかに, 一部の県や市町村農業委員会によ る独自の調查はあったが，系統的なものはなかっ た.

2) これについては筆者 (1972)もふれている. 本稿 における受託・委託は「属人主義」をとっている. 3）例えば，田の見回りに「めったに行かない」 「浜」農家もある。

4)「浜」農家と「在」農家の反収差は小さい。それ は一斉技術指導(稲作ごよみ)に従い，技術の平準 化が進んだからである.
5 ）この場合, もち万ん農家労働力流出の直接的契 機は, 農家労働力が結びつきうる労働市場の賃金 水準と農業所得との相対関係に, 左右されること を否定するものではない.

6 ）全就業者約 3,000 人のうち, 農漁業約 800 人, 商 工業自営約750人, 建設関係(大工・左官・土建等 の自営業) 約 350 人を差し引くと, 賃労働は 1,100 人程度と推定される。

7 ) 信越化学社報 (1976): 「信越化学50周年記念号」; 24 25.

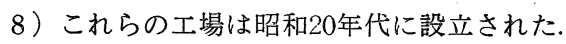

9 ）大工場の技術革新による人員削減は, 規模拡大 によってカバーされ, 求人は昭和 40 年代前半まで 增加した。

10）恒常的貨労働は昭和 40 年の 476 戸が 45 年には 567 戸に増加したが，出稼は85戸が43戸に，人夫・日 雇は106戸が77戸に減少した。

11）この地域の電力は昭和 30 年代には不足となった。

12）昭和 38 年を最高に, 以後著しく減少した.

13）例えば，塩ビ生産におけるカーバイド・アセチ レン法からナフサ利用の技術転換がそれである.

14）全農家 97 戸のうち，0.3 ha 以下 16 戸，0.3 0.5 ha 32 戸, $0.5 \sim 0.7$ ha 25 戸, $0.7 \sim 1$ ha 12 戸, $1 \sim 1.5$ ha 10 戸, $1.5 \sim 2$ ha 2 戸.

15）大潟町の「浜」諸部落は, いずれも零細な业地 規模で, 兼業化が著しい. その点で, 犀潟部落は 一般性をもっている. 直江津地区に近く, 初期の 工場進出部落のため, 安定兼業が早くから多かっ た点に特殊性が求められよう. しかし, その後の 他部落への工場進出や道路整備・自動車の普及は, この部落間の差を埋めている.

16）この数字は農家台帳記載のものから算出したの で，実際はもっと多いとみられる.

17）「浜」における分解基軸の線を $2 \mathrm{ha}$ とみたが， 辟潟ではその線以上の農家は存在しない.「浜」 全体でも 4 戸にすぎない.

18）それでも耕地規模の大小は委託のあり方に一定 の違いをつくりだしている.すなわち $100 \mathrm{a}$ 以下 の耕地規模諸階層では, 委託農家率に大差ないが, $40 \mathrm{a}$ 以下では, 所有地全部を委託する傾向が強く, それ以上では所有地の一部を委託するものが多い.

19）犀潟部落には国立療養所があり，そこの従業員 となっている主婦もいる。

20）とくに犀潟, 渋柿浜の農家は田舟を利用して潟 川ぞいの水田を耕作したのであった。

21）頸城村内に大潟町の農家が約 130 ha 所有する.

22）例えば，通作距離が遠いため，水管理などを地 元の農家がやることが多い. 
23）注 3）に同じ.

24）例えば潟田部落では，白米 3 俵の事例があった. なお県内地域の委託料をいえば，西蒲原で $4 \sim 4.5$ 俵, 新潟市で 3 俵, 魚沼で 3 俵程度となっている.

25）本文中の所有面積, 受託面積と第 6 表のそれぞ れの面積は一致しない，前者はききとり，後者は 農家台帳によるためである.

26）これは農民感情から発している.

27）「組合」は宣伝ビラを出し，委託希望を募った.

28）例えば佐賀県では減少した.

29）新潟県西蒲原では一時的な増勢の鈍化をみせた が，大潟町では一貫して增加しているとみられる.

\section{文 献}

伊藤喜雄（1966）:『稲作中型技術の形成』農政調查 委員会, 119ページ.

伊藤喜雄（1973）：『現代日本農民分解の研究』打茶 の水書房, 517 ページ.

伊藤喜雄（1979）：『農業の技術と経営』家の光協会, 214ページ.

梶井 功 (1977)：『農地法的土地所有の崩壊』農林
統計協会, 241 ページ.

川上 誠（1972）：ゆれ動く米主産地(1) 一新潟・ 蒲原平野一一西川大二郎・野口雄一郎・奥田義 雄編『農山漁村』勁草書房, 23 38.

倉内宗一（1976）：『経営受委託』農政調查委員会, 210 ページ.

近藤康男編（1967）:『米作一新しい波一』打茶の水 書房, 298ページ.

佐藤元重（1977）:『新潟経済小史』新潟日報，444 ページ.

高橋正明(1977)：大阪近郊に打ける稲作の生産組織 化の特貿と問題点——泉大津の場合—. 大手前 女子大学論集, 11, 65 83.

新潟県農林部 (1968)：請負耕作の状況一市町村別一. 『昭和 43 年度農業動向調査報告書』1 6.

農政ジャーナリストの会（1978）：『減反に摇れる農 村』235ページ.

北陸農政局（1971）：『北陸農業情勢報告』178ペー シ.

松井貞雄 (1968)：中京地域に抢ける都市化と近郊農 村地域の対応. 経済地理学年報, 14-1, 1 21.

\section{CONTRACT CULTIVATION OF RICE IN OHGATA-MACHI, NIIGATA PREFECTURE}

\section{Makoto KAWAKAMI*}

Contract cultivation of rice is found throughout Japan. The percentage of contract cultivation of rice in Niigata Prefecture is higher than that of the rest of the nation, and Ohgata-machi has one of the highest percentages of contract cultivation of rice in Niigata Prefecture.

This paper deals with the causes of contract cultivation of rice, the separation of settlements into caretaker-settlements and land-owner settlements, the roles of housewives of farm households in contract farming, and step-wise transition into contract farming, with reference to the relationship between the development of local labor market and the changes in agricultural organizations. Then, the writer investigates the character of caretaker-farms and their processes of enlargement of farm operation, and attempts to find the factors of development of contract farming of rice under the policy of "reducing acreage of rice production".

Absorbing farm laborers into manufacturing plants is one of the causes of creating contract farming of rice. Therefore, contract farming will increase for decades to come. Contract farming, however, means breakdown of owner-operators who were given their lands after World War II and also is a formation of new type of agricultural management.

Geographical Review of Japan $\quad$ 52-12 $661 \sim 674 \quad 1979$

* Haneda Technical High School. 